\section{Initiation and Maturation of Somatic Embryos of Squash (Cucurbito pepo)}

\author{
Paula P. Chee \\ Molecular Biology Research, The Upjohn Company, 301 Henrietta \\ Street, Kalamazoo, MI 49007
}

Additional index words. Cucurbitaceae, growth regulators, plant tissue culture, somatic
embryos, in vitro

Abstract. Plant regeneration from tissue cultures of summer squash (Cucurbita pepo L. ev. YC60) has been observed. Embryogenic callus tissues were initiated when cotyledons of mature seeds were excised and cultured on Murashige and Skoog (MS) medium supplemented with either $22.7 \mu \mathrm{M}$ 2,4-D or a combination of $4.7 \mu \mathrm{M}$ 2,4,5-T, $4 \mu \mathrm{M} \mathrm{BA}$, and $0.5 \mu \mathrm{M}$ kinetin. Clusters of somatic embryos were found in callus tissue. Maturation of these somatic embryos was effected by transfer of embryogenic callus tissues to MS supplemented with $0.5 \mu \mathrm{M}$ NA and $0.25 \mu \mathrm{M}$ kinetin. Regenerated mature plants were morphologically normal and set fruits containing seed that germinated normally. Chemical names used: 6-benzylaminopurine (BA); 2,4-dichlorophenoxyacetic acid (2,4-D); $\alpha$ - napthaleneacetic acid (NAA); 2,4,5-trichlorophenoxyacetic acid $(2,4,5-T)$.

There have been very few studies concerning tissue culture of Cucurbita pepo. Schroder (1968) reported the production of embryogenic tissue from pericarp of zucchini squash. Jelaska (1972, 1973, 1974, 1980) reported somatic embryogenesis in hypocotyl- and cotyledon-derived callus of pumpkins and demonstrated that embryos could develop into normal plants. Pink and Walkey (1984) reported a micropropagation method for pumpkin through apical meristem culture. Chee (1991) reported somatic embryogenesis with plant regeneration from shoot apex-derived callus of summer squash. This report describes a method for induction and maturation of somatic embryos of ' $\mathrm{YC} 60$ ' summer squash from cotyledons of mature seed.

Mature seeds of 'YC 60' summer squash (Asgrow Seed Co., Kalamazoo, Mich.) were surface sterilized for $10 \mathrm{~min}$ with a solution of $5.25 \%$ sodium hypochlorite and rinsed three times with sterile water. After removal of the seedcoats, the seeds were again treated with $8.75 \%$ sodium hypochlorite for $25 \mathrm{~min}$ and rinsed three times with sterile water. The seeds were then treated with $70 \%$ alcohol for $1 \mathrm{~min}$ and rinsed three times with sterile water.

Sterilized embryos were cut transversely into two unequal sections. One section consisted of the embryonic axis and one-third of the cotyledons; the other, the remainder of the cotyledons. The explants, including the embryonic axis, were cultured vertically with the cut surface facing upward; cotyledon explants were cultured with abaxial surface in contact with the culture medium. All cultures were kept in the dark for 9 weeks at

Received for publication 24 Jan. 1991. Accepted for publication 6 Aug. 1991. I thank Krystal A. Parker for plant care in the greenhouse. The cost of publishing this paper was defrayed in part by the payment of page charges. Under postal regulations, this paper therefore must be hereby marked advertisement solely to indicate this fact.
26C. Unless otherwise stated Murashige and Skoog (1962) (MS) medium supplemented with $3 \%$ sucrose and solidified with $0.8 \%$ Phytagar (Gibco, Grand Island, N.Y.) was used. The $\mathrm{pH}$ of all media was adjusted to 5.8 before autoclaving at $121 \mathrm{C}$ for $20 \mathrm{~min}$.

In the first experiment, the effect of 2,4-D (2.3, 4.5, 9.1, 13.6, 22.7, 45.4, 113.5, and $227 \mu \mathrm{M})$ was determined in combination with five concentrations of kinetin $(0,2.3$, 4.6, 9.2, and $13.8 \mu \mathrm{M})$. Between 100 to 170 explants of each type were used per treatment. In the second experiment, the effect of $\beta$-indoleacetic acid (IAA) $(0,8$, and 16 $\mu \mathrm{M})$ was determined in combination with kinetin $(0,6.9,13.8,18.9$, and $27.9 \mu \mathrm{M})$. For each treatment, 120 explants of each type were used. Finally, a combination of $4.7 \mu \mathrm{M}$ 2,4,5-T, $4 \mu \mathrm{M} \mathrm{BA}$, and $0.5 \mu \mathrm{M}$ kinetin (TBK medium) was used. For this treatment, 531 explants of each type were used.

After 9 weeks on the induction media, including one subculture at 4.5 weeks, callus containing putative somatic embryos were transferred to maturation medium composed of MS salts and vitamins with $0.5 \mu \mathrm{M}$ NAA and $0.25 \mu \mathrm{M}$ kinetin. The cultures were incubated at $28 \mathrm{C}$ under diffuse cool-white fluorescent lamps $\left(80 \mu \mathrm{mol} \cdot \mathrm{m}^{-2} \cdot \mathrm{s}^{-1}\right)$ with a 16 $\mathrm{h}$ photoperiod. When the apical region grew, the tissues were transferred to GA7 boxes (Magenta, Chicago) containing $50 \mathrm{ml}$ of halfstrength hormone-free MS medium. After an extensive root system developed, the plantlets were transplanted to 0.9 -liter plastic pots containing planting medium and covered with clear plastic storage bags for 1 week for acclimation. Subsequently, the regenerated plants were potted in 7.6-liter pots containing a soil mixture (Metro Mix 300R; A.H. Hummert Seed Co., St. Louis) and grown in a greenhouse.

Representative embryogenic callus tissues on individual somatic embryos were prepared for microscopic examination by fixing in $10 \%$ neutral buffered formalin for $45 \mathrm{~min}$, dehydrated in an ethyl alcohol-tertiary alcohol series, and embedded in Paraplast (Monoject Scientific, St. Louis) at 56C. Embedded tissues were sectioned at $5 \mu \mathrm{m}$ and stained for $12 \mathrm{~h}$ with $1 \%(\mathrm{v} / \mathrm{v})$ safranin 0 (Sigma Chemical Co., St. Louis) dissolved in $50 \%$ alcohol, followed by a 20 -sec exposure to $1 \%(\mathrm{v} / \mathrm{v})$ fast green (Sigma Chemical Co.) dissolved in 95\% alcohol.

In the first experiment, the only effective treatment for induction of embryogenic callus was $22.7 \mu \mathrm{M} 2,4-\mathrm{D}$ without kinetin. Only $5 \%$ of the explants produced embryos when the cotyledon was present, but $28 \%$ did when the cotyledon and embryonic axis were present.

After 6 weeks of culture on MS containing $22.7 \mu \mathrm{M}$ 2,4-D, both types of explants formed embryonic-type callus that was translucent, smooth, and gelatinous in appearance. Most of this callus developed at the embryonic axis area and at the site of explant contact with the medium. After an 8- to 9-week incubation, $\approx 10$ to 20 putative somatic embryos had formed on the surface of the gelatinous callus (Fig. 1). Similar callus morphology

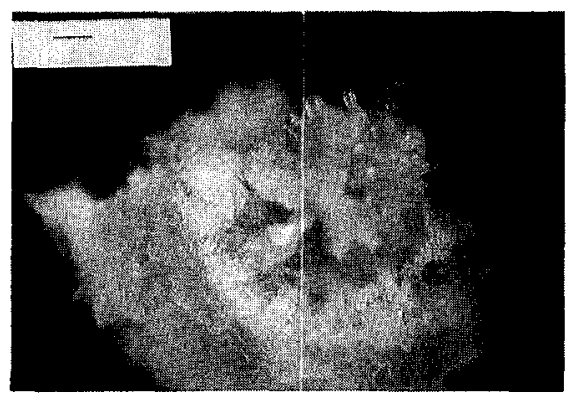

Fig. 1. Cluster of somatic embryos formed on embryonic axis explant. Bar $=1 \mathrm{~mm}$.

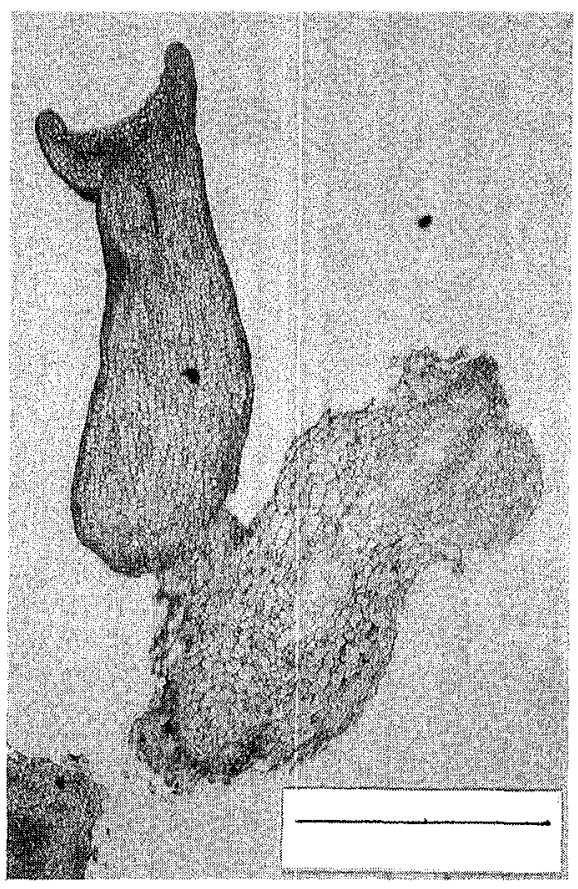

Fig. 2. Longitudinal section of a somatic embryo indicating bipolar structure. $\mathrm{Bar}=0.5$ $\mathrm{mm}$. 


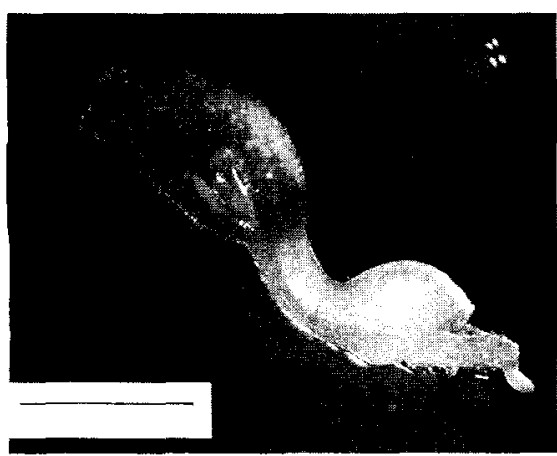

Fig. 3. A maturing somatic embryo 2 weeks after culture on maturation medium. Bar $=1 \mathrm{~mm}$.

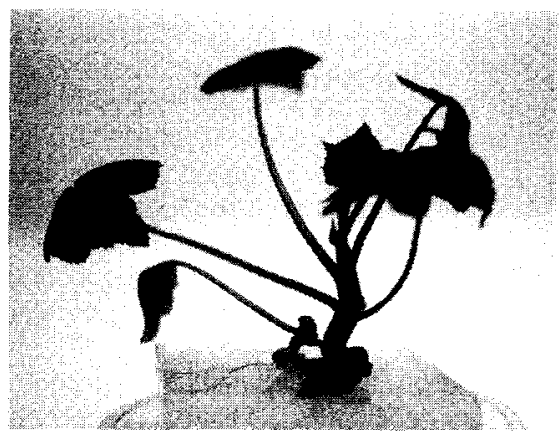

Fig. 4. Plantlet derived from a somatic embryo.

was observed in embryogenic callus tissue derived from cucumber explants (Chee, 1990; Malepsey and Nadolska-Orczyky, 1983). Juretic and Jelaska (1991) have shown that MS medium $+5.7 \mu \mathrm{M}$ IBA $+4.5 \mu \mathrm{M}$ 2,4-D could induce embryogenic callus from hypocotyl explants of pumpkin; with summer squash, a high concentration of $2,4-D$ $(22.7 \mu \mathrm{M})$ alone appears to be effective in inducing embryoid formation.
A longitudinal cross-section of a bipolar somatic embryo before transfer to maturation medium is shown in Fig. 2. The development of the somatic embryos on maturation medium initially appeared abnormal. The embryos were elongated with distorted morphology (Fig. 3); however, $-75 \%$ of these embryos developed into normal plantlets (Fig. 4).

Root formation was obtained when the mature embryos were grown on half-strength MS basal medium without growth regulators. The success of transfer of the plantlets from agar to planting medium was $100 \%$. Two-hundred plants regenerated in this manner displayed no gross phenotypic abnormalities; they flowered and set viable seeds.

In the second experiment (IAA combined with kinetin), callus tissues grew very slowly on all test media. Some tissues became markedly nodular, rhizogenic, and brownish, but embryogenic, gelatinous-type tissues were absent. Jelaska (1974) reported that embryogenic callus tissues were induced on pumpkin hypocotyl explants cultured on media supplemented with 5.6 to $11.2 \mu \mathrm{M}$ IAA. However, with summer squash IAA does not appear to have any induction effect on the explants.

With TBK medium, somatic embryogenesis was observed only on the explants containing the embryonic axis; $8 \%$ of the explants produced embryogenic tissue. Embryoids initially appeared abnormal; however, nearly $50 \%$ of them grew into plantlets. Regenerated plants were morphologically normal, flowered, and set seeds.

To my knowledge, this is the first report of the induction of somatic embryos, and their maturation to plants, of summer squash from mature seeds. Mature seeds provide a convenient and readily available explant source. Initiation of embryogenic cultures is simple and rapid. Putative embryogenic tissue that developed on the surface of the explant was easily identified by a characteristic translucence. Plantlets were obtained within 4 months of culture initiation. Further studies are needed to determine if this protocol is genotype-specific.

\section{Literature Cited}

Chee, P.P. 1990. High frequency of somatic embryogenesis and recovery of fertile cucumber plants. HortScience 25:792-793.

Chee, P.P. 1991. Somatic embryogenesis and plant regeneration of squash Cucurbita pepo L. cv. YC60. Plant Cell Rpt. 9:620-622.

Jelaska, S. 1972. Embryoid formation by fragments of cotyledons and hypocotyls in Cucurbita pepo. Planta 103:278-280.

Jelaska, S. 1973. Growth of fragments of mature pumpkin embryos cultivated in vitro. Acta Bot. Croatia 32:81-94.

Jelaska, S. 1974. Embryogenesis and organogenesis in pumpkin explants. Physiol. Plant. 31:257-261.

Jelaska, S. 1980. Growth and embryoid formation in Cucurbita pepo callus culture, p. 172-178. In: C. Doré (ed.). Application de la culture in vitro à l'amélioration des plantes Potagères. INRA, Versailles, France.

Juretic, B. and S. Jelaska. 1991. Plant development in long-term embryogenic callus lines of Cucurbita pepo. Plant Cell Rpt. 9:623-626.

Malepsey, S. and A. Nadolska-Orczyk. 1983. In vitro culture of Cucumis sativus. Z. Pflanzenphysiol. 111:273-276.

Murashige, T. and F. Skoog. 1962. A revised medium for rapid growth and bioassays with tobacco tissue cultures. Physiol. Plant. 15:473497.

Pink, D.A.C. and D.G.A. Walkey. 1984. Rapid propagation of Cucurbita pepo L. by culture of meristem tips. Scientia Hort. 24(2):107-114.

Schroder, C.A. 1968. Adventive embryogenesis in fruit pericarp tissue in vitro. Bot. Gaz. 129:374-376. 